УДК 640.412-025.12:502.17

DOI: $10.15673 /$ fie.v13i3.2136

Тітомир Л.А.

кандидат технічних наук, доцент кафедра готельно-ресторанного бізнесу

E-mail: mila_titomir@ukr.net

ORCID ID: 0000-0001-8676-4674

\section{Коротич О.М. \\ асистент}

кафедра готельно-ресторанного бізнесу

E-mail: kelena1811@gmail.com

ORCID ID: 0000-0002-2680-976X

\author{
Халілова-Чуваєва Ю.О. \\ кандидат політології, доцент \\ кафредра готельно-ресторанного бізнесу \\ Одеська національна академія харчових технологій \\ вул. Канатна, 112, м. Одеса, Україна, 65039 \\ E-mail: julik6446@gmail.com \\ ORCID: 0000-0002-1935-7793
}

\title{
ЕКОЛОГІЗАЦІЯ ГОТЕЛІВ ЯК НАПРЯМ РОЗВИТКУ ГОТЕЛЬНО- РЕСТОРАННОГО БІЗНЕСУ
}

\begin{abstract}
Екоготелі - $€$ перспективним напрямом розвитку індустрії гостинності. Південний регіон України володіє всіма необхідними ресурсами для створення екоготелів. В статті обґрунтована розробка концепції та проектування готелю екологічного спрямування. Попит споживачів на екологічні послуги розміщення значно переважає пропозицію. Досліджуються можливі шляхи виконання критеріїв міжнародної програми Green Key для можливого подальшого отримання сертифрікату екологічного засобу розміщення. Розглянуті особливості проектування готелю із використанням сучасних будівельних енергоефективних технологій. Для контролю та зменшення споживання води пропонуються системи інтелектуального управління та інші заходи скорочення витрат. В готелях південних регіонів доцільно використовувати сонячну енергію, яку пропонується залучити для нагрівання води за допомогою термосифонних геліосистем. В екоготелі необхідно правильно поводитись з відходами, розподіляти та повторно перероблювати їх. Харчові відходи пропонується компостувати та використовувати в якості добрив. Частина відходів може відійти компанії з переробки. Для надання харчування пропонується заклад локальної кухні, для якого можна використовувати продукцію місцевих фермерів.
\end{abstract}

Ключові слова: екоготелі, екологічна сертифрікація, тенденції розвитку готелів, технології будівництва готелів, проектування готелів

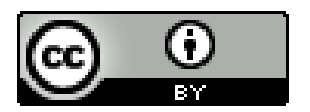

This work is licensed under a Creative Commons Attribution 4.0 International License http://creativecommons.org/licenses/by/4.0/
Постановка проблеми та її зв'язок з важливими науковими та практичними завданнями. Охорона навколишнього середовища є обов'язковим напрямом діяльності всіх сфер бізнесу. Сталий розвиток неможливий без дотримання необхідних норм та умов стосовно навколишнього середовища. Світова громадськість та науковці наголошують про важливість еконаправленості підприємств. Заклади гостинності також повинні розвиватись на шляху до екологічності з багатьох причин. По-перше, готелі - це густий осередок споживачів, кожен $з$ яких несе свій слід у екосистемі, а заклад загалом має значний вплив на навколишнє середовище. Без дбайливого відношення 3 часом умови функціонування погіршяться і принесуть збитки. По-друге, екостурбованість - це основний тренд серед споживачів послуг. Тому екоспрямованість готелю стає одним із факторів конкурентоспроможності, збільшення кількості споживачів та прибутку. Свропейські розвинуті країни проводять політику сталого розвитку вже досить довгий час і вбачають перспективи подальшого розвитку індустрії гостинності саме у екологічності [1]. Україна є частиною європейської спільноти, приймає іноземних туристів, тому екоготелі є популярним напрямком розвитку індустрії гостинності. Проблема українського бізнесу стоїть у екосертифікації, так як виконувати критерії та отримувати еколейбли підприємці не прагнуть. Екоготель в Україні - це частіше рекламний хід, ніж реальні дії. Хоча природні та технологічні ресурси дозволяють створювати екоготелі. Попит на дані готельні послуги також вже присутній і серед внутрішніх споживачів.

Зважаючи на сучасний стан всесвітньої пандемії Covid-19 екологічні готелі також займають виграшні позиції. Екологізація - це додаткова безпека здоров'я. Органічна кухня підтримує сильний імунітет. Натуральні та гіпоалергенні матеріали в оснащенні готелю чинять лише позитивний вплив на організм людини. Озеленення територій та внутрішніх просторих приміщень надає чистіше повітря та сприятливі умови для проживання, оздоровлення та відпочинку. З'явились фактори, що погіршують 
екологічні показники (підвищення кількості відходів, обов'язкове індивідуальне пакування та ін.). Сучасний стан діяльності готелів призвів до пошуку нових екологічних заходів та стратегій розвитку [2].

Останні десятиріччя готельний бізнес України динамічно розвивається. Значні зміни внесені за рахунок входження до ринку готельних послуг міжнародних мереж таких, як Rixos, Rezidor, Hyatt, Wyndham Hotel Group. Політика їх діяльності внесла корективи в конкурентне становище галузі. Ознаками ефективного готельного об'єкту є високий рівень та контроль якості послуг, екологічна спрямованість, сучасне оснащення та інноваційні технології.

Аналіз останніх публікацій. Створенню екоготелей у світі передував підвищений інтерес до змін у навколишньому середовищі, пошук можливих рішень їх зупинити та зменшити наслідки після функціонування людини як споживача та виробника. Екоспрямовані заклади створюються у відповідь на попит споживачів. Екологічний менеджмент направлений на підвищення екосвідомості як персоналу закладів, так і їх споживачів [3, 4]. Якщо розглядати останні розробки серед технологій у готелі, то більшість інновацій спрямовано на зменшення споживання води, енергії, зниження кількості та переробку відходів $[5,6]$. Вітчизняні дослідники наводять економічні обгрунтування створення екоготелів $[7,8]$ та перспективи їх функціонування $[9,10]$.

Формулювання цілей дослідження. Метою дослідження стало вивчення попиту на послуги екоготелю та обгрунтування можливості створення закладу із виконанням критеріїв міжнародної сертифікації. Для цього були використані наукові методи дослідження у сфері готельно-ресторанного бізнесу: моніторинг інформаційних ресурсів, аналіз статистичних даних, моделювання технологічних процесів та структурних елементів готелю.

Виклад основних результатів та їх обгрунтування. Для концепції екоготелю обрали відому європейську програму Green Key, за якою готель може отримати сертифікацію екологічного засобу розміщення, виконуючи ряд критеріїв [11]. За вимогами екологічної сертифікації категорія готелю («зірковість») не конкретизується. Екологічним засобом розміщення може бути як база відпочинку з бюджетним рівнем послуг, так і комфортабельний готель високої категорії. Аналіз засобів розміщення з сертифікатом Green Key показав, що більшість таких готелів мають високу категорію [11]. Застосування сучасних високотехнологічних засобів з екологізації призведе до значних витрат на етапі будівництва готелю. Тому доцільніше створювати екоготель 3 категорією 4-5 зірок, тарифи на послуги в якому швидко повернуть витрачені кошти. Нами обгрунтовано можливість проектування екоготелю на півдні України. Цей регіон має достатньо великий потенціал рекреаційних та природних ресурсів для створення засобів розміщення; привертає увагу достатньої кількості туристів іноземних та внутрішніх, яких не відлякує цінова політика готелів високих категорій та рівня послуг.

Регіон володіє рядом об'єктів готельного господарства, що називають себе «екоготелями». Більшість 3 них не має категорійності та відноситься до засобів розміщення особливого типу (дерев'яні котеджі). Приклади та їх екологічні ознаки вказані в таблиці 1.

Таблиця 1

Аналіз екологічних ознак у готелях південного регіону *

\begin{tabular}{|c|c|c|c|c|}
\hline Готель & Особливості будівлі & Органічна кухня & $\begin{array}{l}\text { Використання } \\
\text { екологічних } \\
\text { матеріалів }\end{array}$ & Екологічна політика \\
\hline $\begin{array}{l}\text { Екоготель Villa } \\
\text { Pinia } 3 * \text {, Одеса }\end{array}$ & $\begin{array}{l}\text { максимальне вико- } \\
\text { ристання природно- } \\
\text { го світла та тепла, } \\
\text { панорамне остек- } \\
\text { лення }\end{array}$ & $\begin{array}{l}\text { в ресторані ви- } \\
\text { користовується } \\
\text { сировина } 3 \text { ферм } \\
\text { Одеського регіо- } \\
\text { ну }\end{array}$ & $\begin{array}{l}\text { текстиль із натураль- } \\
\text { них тканин; } \\
\text { сертифіковані мийні } \\
\text { засоби }\end{array}$ & $\begin{array}{l}\text { імідж екоготелю; } \\
\text { підвищення екосві- } \\
\text { домості; навчання } \\
\text { персоналу }\end{array}$ \\
\hline $\begin{array}{l}\text { Eco Apart Hotel } \\
\text { Provence, Одеса }\end{array}$ & деревяні будівлі & $\begin{array}{l}\text { харчування } \quad \text { не } \\
\text { надається }\end{array}$ & $\begin{array}{l}\text { номери оснащені гі- } \\
\text { поалергенними мате- } \\
\text { ріалами }\end{array}$ & $\begin{array}{l}\text { повторне викорис- } \\
\text { тання рушників }\end{array}$ \\
\hline $\begin{array}{l}\text { Екоготель «Чорне } \\
\text { море», Коблеве } \\
\end{array}$ & дерев’яні будівлі & локальна кухня & $\begin{array}{l}\text { номери оснащені де- } \\
\text { рев'яними меблями }\end{array}$ & відсутня \\
\hline $\begin{array}{l}\text { Eco home } \\
\text { «Green's», Чорно- } \\
\text { морськ }\end{array}$ & дерев'яні будівлі & $\begin{array}{l}\text { локальна дома- } \\
\text { шня кухня }\end{array}$ & $\begin{array}{l}\text { текстиль із натураль- } \\
\text { них тканин, дерев'яні } \\
\text { меблі }\end{array}$ & відсутня \\
\hline $\begin{array}{l}\text { Hotel Richard by } \\
\text { Ribas } 3 *, \text { Грибівка, }\end{array}$ & $\begin{array}{l}\text { дерев’яні будівлі, } \\
\text { панорамні вікна }\end{array}$ & відсутня & $\begin{array}{l}\text { гіпоалергенні тексти- } \\
\text { льні матеріали }\end{array}$ & $\begin{array}{l}\text { повторне викорис- } \\
\text { тання рушників }\end{array}$ \\
\hline
\end{tabular}

$$
\text { *Складено авторами на основі офіційних сайтів закладів }
$$

Бачимо, що жоден готель не виконує критеріїв програми Green Key. Більшість готелів можуть запропонувати обмежені пропозиції екологічної спрямованості, які використовуються з рекламними ціля- ми для привертання уваги споживачів.

Перше, на що звертається увага в екозакладі - це екологічна політика та менеджмент. Це пояснюється тим, що якраз з еконаправленності організації 
та контролю виконання вимог починається будь-який екологічний заклад. Екологічність повинна спостерігатись у всіх сферах діяльності закладу. Менеджер чи управляюча особа може поєднувати також і посаду менеджера 3 екологічної політики. До його обов'язків буде входити впровадження екологічних заходів на підприємстві, контроль їх виконання, постійний моніторинг. До екологічної політики залучається максимально увесь персонал закладу. Перешкод для проведення екологічної політики у закладах готельного господарства України немає. Більше того, все більша кількість підприємств переходить на такий рівень управління на запит споживача.

Підтвердити ці факти можна за допомогою статистичних даних, зібраних шляхом опитування адміністраторів готелів та їх споживачів. Наприклад, в Одеському регіоні України розташовується досить велика кількість готелів різних типів та категорій. Проведено опитування за допомогою платформи Google. Дослідження підвищення попиту на екоорієнтовані послуги розміщення та відповідно проведення політики в готелях регіону відображено на діаграмі (рис. 1).

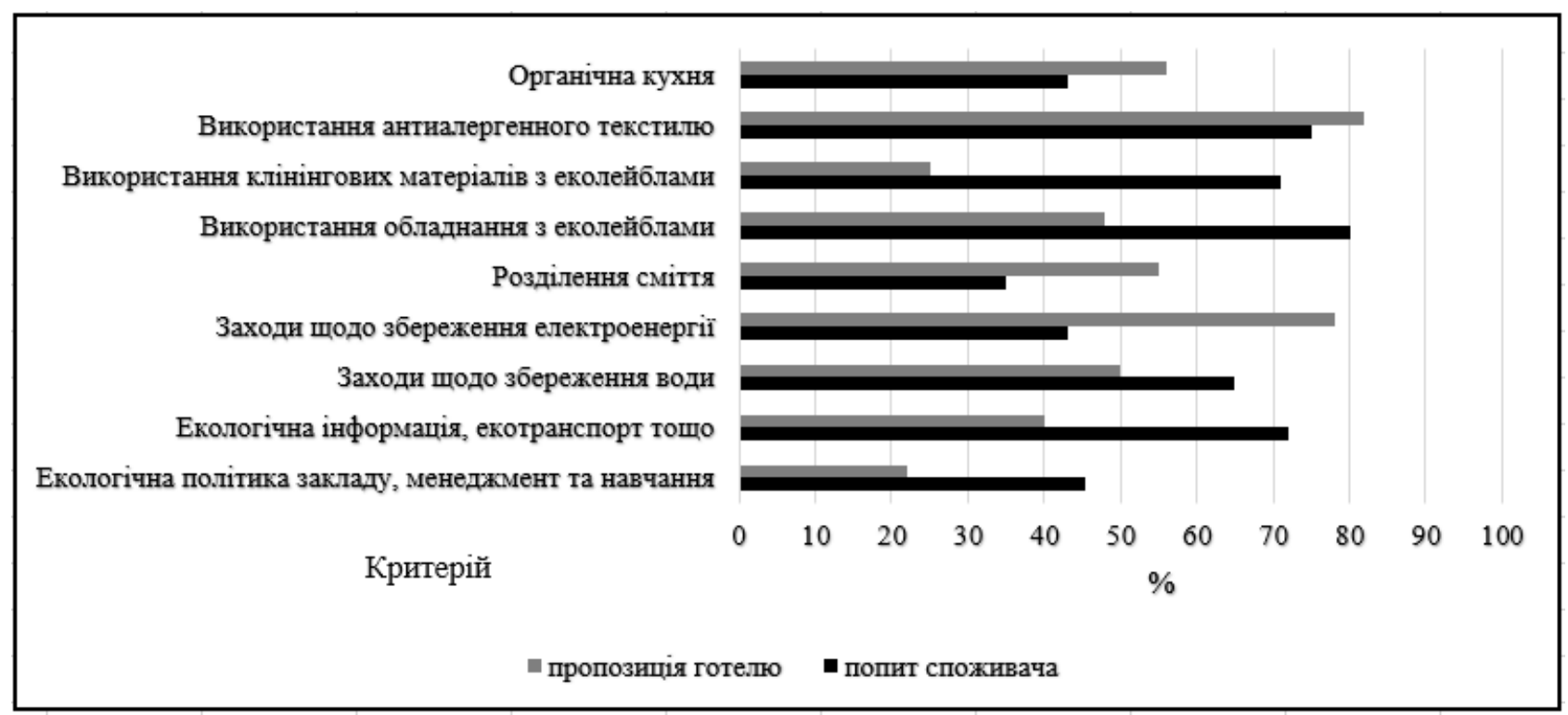

Рис. 1. Аналіз попиту та пропозицій послуг екоготелю*

*складено авторами

Бачимо, що запит споживача значно переважає пропозиції послуг, тому актуальним є відкриття саме екоготелів.

Наступним етапом організації екологічного закладу є залучення персоналу до екологічних ініціатив. На підприємстві повинні регулярно проводитись зібрання щодо існуючих та нових розробок у сфері охорони навколишнього середовища. В регіоні для підвищення обізнаності персоналу можна проводити освітні заходи: консультації, семінари із запрошенням фахівців в галузі. В Одесі є низка закладів вищої освіти, які можуть надати фахівців-освітян 3 екології. Крім того, в Україні функціонують вже багато міжнародних організацій, що надають консультативні послуги з екологічної політики та діяльності у різних сферах бізнесу.

Після створення концепції екоготелю переходять до етапу його проектування. На основі проекту готелю потім відбувається його будівництво, тому у проекті екоготелю повинні бути закладені всі технологічні та будівельні особливості. Підприємець може обрати екоспрямування готелю вже на етапі будівництва. Будівельні компанії України та світу пропонують енергоефективні будівельні технології, що вже можемо спостерігати у готових відбудованих проектах [12, 13, 14]. У південному регіоні найбільш поширена «канадська технологія» будівництва із SIPпанелей (від англ. «structural insulated panel»- структурна ізоляційна панель) $[14,15]$. Стіни будівлі представлені із високощільного пінополістиролу та дерев'яних плит, поєднаних у єдину утеплену конструкцію. Такий матеріал перевищує у 4 рази за теплоізоляцією звичні цегляні, газобетонні чи панельні залізобетонні стіни [15]. Використання цієї технології при будівництві екоготелю дозволить зменшити втрати тепла, збереже прохолоду влітку у приміщеннях та знизить витрати на обігрів взимку.

Розташування та конструкція будівлі готелю повинні обиратись таким чином, щоб максимально використовувати сонячну теплову енергію та освітлення. Для готелю, що функціонуватиме взимку, важливо обрати енергоефективні системи вікон та дверей. Всі житлові приміщення проектуються із максимальним доступом природного світла.

Одним із найбільш важливих критеріїв екоготелю є постійний контроль за витратами води та енергії і заходи щодо їх зменшення. Для водопостачання екоготелю пропонуємо використати системи 
інтелектуального управління водою (наприклад, німецького виробництва GROHE SENSE SET). До складу системи входить розумний контролер води, який виконує функції визначення витрат води, виявлення пошкоджень труб, мікропротікань, визначення температури для уникнення промерзання. Він визначає швидкість потоку і тиск води в системі, рівень вологості. Контроль виконується завдяки системі світлового LED-індикатору, звукового сигналу та мобільного додатку GROHE Ondus для iOS и Android. За допомогою мобільного додатку $\epsilon$ можливість настройки всіх параметрів. При пошкодженнях водопроводів система автоматично відключає подавання води. Також до складу системи входять три інтелектуальні датчики витрат води, що розташовують у місцях найбільшого використання. Таким чином можна буде проводити регулярний облік витрат води та аналіз загального споживання. Крім того встановлюються унітази з двома варіантами змиву, насадки для аерації потоку води у кранах загального користування. Регулярно персоналом служби прибирання перевіряються крани та унітази на справність для запобігання витрат води у вигляді крапель. Стічні води можна відстоювати та використовувати повторно для поливу зелених насаджень на території готелю.

При наявності у проекті басейну, він планується із розсувним павільйоном і проектується таким чином, щоб максимально нагріватись сонячними променями. Очищення та пом'якшення води проводиться за допомогою природних мінералів.

Для збереження енергії в готелі використовується лише LED-освітлення, що економить до 40-60 \% електроенергії в порівнянні 3 іншими джерелами світла. Такі лампочки підлягають повторній переробці та не забруднюють навколишнє середовище. Вони майже не виділяють тепла, не випромінюють ультрафіолетові та інфрачервоні промені, тому абсолютно безпечні для рослин та людини. В денний час освітлення повністю забезпечується природним сонячним джерелом за рахунок вдалого розміщення та достатньої кількості вікон. Зовнішнє освітлення має автоматичний датчик вимкнення, що реагує на рух.

Сонячна енергія також використовується для нагрівання води. 3 цією метою встановлюються термосифонні геліосистеми, які є найбільш простими в монтажі та вимагають мінімум інвестицій. Такі системи є ідеальними для сезонного використання в готелях півдня України. Вони розташовуються на даху будівлі готелю та підкреслюють його екологічний імідж.

Для екологічно вірного поводження 3 відходами має проводитись їх обов'язкове сортування. Сортування сміття організовується як в номерах, так i в загальних приміщеннях готелю та у виробничих цехах закладу харчування. Органічні відходи компостуються та використовуються як добрива для озеленення. Велика частина відходів може йти на вторинне перероблення, що легко можна організувати завдяки співпраці з компаніями з переробки відходів (наприклад, «Втор-ресурси» у південному регіоні).

Особлива увага надається клінінговим технологіям та використанню сучасного обладнання. Із входженням до євроспільноти країна отримала кра- щий доступ до постачальників матеріалів та обладнання $з$ екосертифікацією. Сьогодні створення нового виробничого обладнання неможливе без функції дбайливості про навколишнє середовище. У виробничих приміщеннях готелю повинні використовуватись відповідне промислове обладнання та супровідні матеріали. Служба клінінгу готелю повинна використовувати екосертифіковані матеріали та технології.

За критеріями екологічних міжнародних програм у екоготелі повинні обирати органічну кухню. Цей термін означає використання місцевої сировини або продукції з еколейблами, акцентування уваги в меню на ці продукти; зменшення вживання в їжу м'яса та викреслення зі списку сировини зникаючих видів тварин, риби, морепродуктів тощо; створення вегетаріанського чи веганського меню; пакування в одноразовий посуд лише за необхідністю та з матеріалів, що вторинно переробляються; зниження рівня харчових відходів. Пропонуємо створення ресторану локальної кухні. Для виготовлення страв буде використовуватись продукція місцевих фермерів. Південний регіон багатий на різноманітні види сировини це і якісна рослинна сировина, і продукція тваринництва. Тут присутні виноробні підприємства та невеликі сироварні. Наявність моря та річок дає можливість використовувати свіжу рибу та морепродукти. Заклад харчування при екоготелі повинен надавати в першу чергу якісну та органічну їжу, що можливо шляхом постійного контролю та дотримання вимог.

У сучасних умовах розвитку та попиту екологічність готельного продукту є обов'язковою вимогою для конкурентного засобу розміщення. Більшість іноземних туристів обирають готелі за корпоративним кодексом за умови екологічної сертифікації. Екоготель за міжнародними умовами сертифікації надає високу якість послуг та сучасне оснащення - ті основні ознаки, за якими формується попит на готельні послуги. Екологічне спрямування готелю дає додатковий прибуток за рахунок зацікавлених споживачів, скорочення витрат на ресурси, надання супутніх додаткових послуг. За міжнародною програмою сталого розвитку екологізація закладів гостинності має позитивний вплив на всі сфери діяльності та економічний розвиток держави за рахунок використання енергоефективних технологій, збереження природних ресурсів та екологічного виховання спільноти.

Висновки та перспективи подальших досліджень. В результаті проведених досліджень можемо зробити висновок, що будівництво першого екоготелю за всіма критеріями міжнародної екологічної програми може бути реальним на півдні України. Запропоновані шляхи виконання міжнародних вимог екологічної сертифікації. Будівництво екоготелю $\epsilon$ доцільним завдяки наявності природних ресурсів, розроблених сучасних будівельних технологій, практичним заходам по збереженню невідновлювальних ресурсів та існуючому попиту на екологічні послуги розміщення. Подальші дослідження можливі у детальному вивченні факторів впливу на конкурентоспроможність екоготелю, економічному обгрунтуванні проекту будівництва, аналізі тенденцій екологічного дизайну житлового фонду тощо. 


\title{
Література
}

1. Misso R., Andreopoulou Z., Cesaretti G. P., Hanna S. S., Tzoulis I. Sustainable development and green tourism: New practices for excellence in the digital era // Journal for International Business and Entrepreneurship Development. 2018. Vol. 11, № 1. P. 65-74. doi: 10.1504/JIBED.2018.090035

2. Ferreira S., Pereira O., Simoes C. Environmental Sustainability in the Hotel Industry: A Perspective from Eco Hotel Managers in Portugal // International Journal of Marketing Communication and New Media. 2021. P. 150170 .

URL:

https://mail.google.com/mail/u/0/\#inbox/FMfcgzGlkPcpjCmTfkLNbMKkfXgPqNnC?projector=1\&messagePartId=0.2 (дата звернення: 1.08.2021).

3. Hou H., Wu H. Tourists' perceptions of green building design and their intention of staying in green hotel // Tourism and Hospitality Research. 2021. Vol. 21, № 1. P. 115-128. doi: 10.1177/1467358420963379

4. Han H., Yu J., Lee J. S., Kim, W. Impact of hotels' sustainability practices on guest attitudinal loyalty: Application of loyalty chain stages theory // Journal of Hospitality Marketing \& Management. 2019. Vol. 28, № 8. P. 905-925. doi: 10.1080/19368623.2019.1570896

5. Cingoski V., Petrevska, B. Making hotels more energy efficient: the managerial perception // Economic research-Ekonomska istraživanja. 2018. Vol. 31, № 1. P. 87-101. doi: 10.1080/1331677X.2017.1421994

6. Rico A., Olcina J., Baños C., Garcia X., Sauri D. Declining water consumption in the hotel industry of mass tourism resorts: Contrasting evidence for Benidorm, Spain // Current Issues in Tourism. 2020. Vol. 23, № 6. P. 770-783. doi:10.1080/13683500.2019.1589431

7. Грановська В. Г., Бойко В. О. Функціонування екоготелів в Україні як чинник активізації підприємницької діяльності // Економіка АПК. 2020. № 3. С. 57-65. doi: 10.32317/2221-1055.202003057

8. Загорянська О. Л. Оцінка конкурентоспроможності екологічних готелів у сучасних умовах господарювання // Глобальні та національні проблеми економіки. 2018. № 22. С. 662-668.

9. Барна М. Ю., Гліненко Л. К., Дайновський Ю. А. Екотуризм як фактор розвитку туристичного і готельного бізнесу // Підприємництво 2020. № 27. С. 82-89. doi: 10.36477/2522-1256-2020-27-15

10. Шувар Н. М., Закалик Г. М., Удуд І. Р. Перспективи розвитку екоготелів в Україні: економічний і психологічний аспекти // Економіка і суспільство. 2018. № 15. С. 322-323.

11. Green Key: [Веб-сайт]. URL: https://www.greenkey.global (дата звернення: 1.08.2021).

12. Solanki A., Nayyar A. (ed.). Green Building Management and Smart Automation: IGI Global, 2019. 312 p. doi: 10.4018/978-1-5225-9754-4

13. Teng J., Mu X., Wang W., Xu C., Liu W. Strategies for sustainable development of green buildings // Sustainable Cities and Society. 2019. Vol. 44. P. 215-226. doi: 10.1016/j.scs.2018.09.038

14. Новомлинець О.О., Олексієнко С.В., Ющенко С.М., Нагорна І.В. Перспективи розвитку екологічно чистого будівництва в Україні // Нові технології в будівництві. 2020. № 37. С. 38-43

15. Сервус Одеса. Будівництво за канадською технологією під ключ: [Веб-сайт]. Одеса, 2021. URL: https://servusbud.od.ua (дата звернення: 1.08.2021).

Стаття надійшла 11.08.2021 Стаття прийнята до друку 25.08.2021 Доступно в мережі Internet 24.10.2021

Titomyr L.

PhD., Associate Professor

Department of Hotel and Restaurant Business

E-mail: mila_titomir@ukr.net

ORCID ID: 0000-0001-8676-4674

\section{Korotych 0. \\ Assistant}

Department of Hotel and Restaurant Business

E-mail: kelena1811@gmail.com

ORCID ID: 0000-0002-2680-976X

\author{
Khalilova-Chuvaieva Y. \\ PhD., Associate Professor \\ Department of Hotel and Restaurant Business \\ Odesa National Academy of Food Technologies \\ Kanatna str., 112, Odesa, Ukraine, 65039 \\ E-mail: julik6446@gmail.com \\ ORCID: 0000-0002-1935-7793
}

\section{HOTEL GREENING AS A DIRECTION OF HOTEL AND RESTAURANT BUSINESS DEVELOPMENT}

Eco-hotels are a promising direction of the hospitality industry development. The southern region of Ukraine has all the necessary resources to create eco-hotels. The development of the concept and design of an ecological hotel has been substantiated in the article. The consumer demand for ecological accommoda- 
tion services significantly exceeds the supply, which is proved by the conducted surveys and analysis of the hotel services market. There are several hotels in the region that strive for environmental friendliness, but do not fulfill international conditions. Possible ways of fulfilling the criteria of the international Green Key program are being investigated to further obtain a certificate of an ecological accommodation. The concept of an ecohotel begins with environmental management and personnel environmental education. Environmental policy is about attracting consumers. The features of hotel design using modern energy-efficient building technologies, which are already used in the world and in Ukraine, have been considered. Intelligent water management systems and other waste reduction measures have been proposed to control and reduce water consumption. In south regional hotels, it is advisable to use solar energy, which is proposed to be attracted to heat water using thermosiphon solar systems. In an eco-hotel, it is necessary to properly handle waste, distribute and recycle it. Food waste is proposed to be composted and used as fertilizer. Some of the waste can be collected by a recycling company. To provide meals, a local cuisine establishment is proposed, local farmers products can be used. Sustainability has become a mandatory component of a hotel product in a successful hotel business. Hotels must strive for sustainability in order to comply with the international sustainability agenda. The creation of an eco-hotel is economically and socially efficient, thanks to the use of energy efficient technologies, the preservation of natural resources and the community ecological education.

Key words: eco-hotels, environmental certification, hotel development trends, hotel construction technologies, hotel design.

\section{References}

1. Misso, R., Andreopoulou, Z., Cesaretti, G. P., Hanna, S. S., \& Tzoulis, I. (2018). Sustainable development and green tourism: New practices for excellence in the digital era. Journal for International Business and Entrepreneurship Development, 11(1), 65-74. doi: 10.1504/JIBED.2018.090035

2. Ferreira, S., Pereira, O., \& Simoes, C. (2021). Environmental Sustainability in the Hotel Industry: A Perspective from Eco Hotel Managers in Portugal. International Journal of Marketing Communication and New Media, 150-170. $\quad$ Retrieved August $\quad 01, \quad$ from https://mail.google.com/mail/u/0/\#inbox/FMfcgzGlkPcpjCmTfkLNbMKkfXgPqNnC?projector=1\&messagePartId=0.2

3. Hou, H., \& Wu, H. (2021). Tourists' perceptions of green building design and their intention of staying in green hotel. Tourism and Hospitality Research, 2l(1), 115-128. doi: 10.1177/1467358420963379

4. Han, H., Yu, J., Lee, J. S., \& Kim, W. (2019). Impact of hotels' sustainability practices on guest attitudinal loyalty: Application of loyalty chain stages theory. Journal of Hospitality Marketing \& Management, 28(8), 905-925. doi: 10.1080/19368623.2019.1570896

5. Cingoski, V., \& Petrevska, B. (2018). Making hotels more energy efficient: the managerial perception. Economic research-Ekonomska istraživanja, 31(1), 87-101. doi: 10.1080/1331677X.2017.1421994

6. Rico, A., Olcina, J., Baños, C., Garcia, X., \& Sauri, D. (2020). Declining water consumption in the hotel industry of mass tourism resorts: Contrasting evidence for Benidorm, Spain. Current Issues in Tourism, 23(6), 770-783. doi:10.1080/13683500.2019.1589431

7. Hranovska, V. H., Boiko, V. O. (2020). Funktsionuvannia ekohoteliv v Ukraini yak chynnyk aktyvizatsii pidpryiemnytskoi diialnosti. Ekonomika APK, (3), 57-65. doi: 10.32317/2221-1055.202003057

8. Zahorianska, O. L. (2018). Otsinka konkurentospromozhnosti ekolohichnykh hoteliv u suchasnykh umovakh hospodariuvannia. Hlobalni ta natsionalni problemy ekonomiky, (22), 662-668.

9. Barna, M. Yu., Hlinenko, L. K., \& Dainovskyi, Yu. A. (2020). Ekoturyzm yak faktor rozvytku turystychnoho i hotelnoho biznesu. Pidpryiemnytstvo i torhivlia, (27), 82-89. doi: 10.36477/2522-1256-2020-27-15

10. Shuvar, N. M., Zakalyk, H. M., \& Udud, I. R. (2018). Perspektyvy rozvytku ekohoteliv v Ukraini: ekonomichnyi i psykholohichnyi aspekty. Ekonomika i suspilstvo, (15), 322-323. doi:10.1111/iwj.12948

11. Green Key. Retrieved August 01, 2021, from https://www.greenkey.global

12. Solanki, A., \& Nayyar, A. (ed.). (2019). Green Building Management and Smart Automation: IGI Global. doi: 10.4018/978-1-5225-9754-4

13. Teng, J., Mu, X., Wang, W., Xu, C., \& Liu, W. (2019). Strategies for sustainable development of green buildings. Sustainable Cities and Society, 44, 215-226. doi: 10.1016/j.scs.2018.09.038

14. Novomlynets, O. O., Oleksiienko, S. V., Yushchenko, S. M., \& Nahorna, I. V. (2020). Perspektyvy rozvytku ekolohichno chystoho budivnytstva v Ukraini. Novi tekhnolohii v budivnytstvi, (37), 38-43.

15. Servus Odesa. Budivnytstvo za kanadskoiu tekhnolohiieiu pid kliuch (2021). Retrieved August 01, 2021, from https://servusbud.od.ua

Received 11 August 2021

Approved 25 August 2021

Цитування згідно ДСТУ 8302:2015

Available in Internet 24.10.2021

Тітомир Л.А., Коротич О.М., Халілова-Чуваєва Ю.О. Екологізація готелів як напрям розвитку готельно-ресторанного бізнесу // Економіка харчової промисловості. 2021. Т.13, вип. 3. C.88-93. doi: 10.15673/fie.v13i3.2136

Cite as APA style citation

Titomyr, L., Korotych, O. \& Khalilova-Chuvaieva, Y. (2021). Hotel greening as a direction of hotel and restaurant business development. Food Industry Economics, 13(3), 88-93. doi: 10.15673/fie.v13i3.2136 